\title{
Analisis Simpang Simpang Empat Bersinyal Wirobrajan Akibat Perubahan Urutan Fase Menggunakan PTV VISSIM
}

\author{
Aprilia Wulandari ${ }^{\mathrm{a}}$, Muchlisin ${ }^{\mathrm{b} *}$ \\ ${ }^{a}$ Mahasiswa Magister Sistem dan Teknik Transportasi, Universitas Gadjah Mada \\ ${ }^{b}$ Program Studi Teknik Sipil, Fakultas Teknik, Universitas Muhammadiyah Yogyakarta
}

Riwayat Artikel

Diserahkan

1 Desember 2020

Direvisi

4 Januari 2021

Diterima

1 Februari 2021

*Penulis korespondensi muchlisin@umy.ac.id

\begin{abstract}
Abstrak
Kemajuan transportasi saat ini berkembang dengan sangat pesat, sehingga dapat menyebabkan terjadinya kemacetan, khususnya pada simpang. Salah satu penyebab lainnya yaitu penggunaan siklus dan urutan fase pada sistem Alat Pengatur Isyarat Lampu Lalulintas (APILL) masih menggunakan urutan fase searah jarum jam atau sebaliknya yang mengakibatkan pengendara harus menunggu lama hingga lampu kembali hijau sedangkan arus lalu lintas di simpang tersebut cukup padat. Salah satu simpang yang mengalami hal tersebut yaitu simpang Wirobrajan yang berada di Kota Yogyakarta. Untuk mengetahui kinerja tingkat pelayanan simpang, dilakukan survei untuk memperoleh nilai volume kendaraan, geometrik, serta waktu siklus. Data-data tersebut kemudian akan digunakan untuk analisis serta pemodelan menggunakan software PTV VISSIM. Hasil yang didapatkan menunjukkan tingkat pelayanan pada simpang Wirobrajan termasuk pada kategori $\mathrm{E}$ (buruk), dengan nilai tundaan sebesar 77,09 detik/kend sehingga membutuhkan evaluasi lebih lanjut. Untuk mencapai hasil yang diinginkan, dilakukan percobaan yaitu dengan mengubah urutan fase, mengoptimalisasikan waktu siklus simpang, serta dilakukan trial and error rasio belok kanan dan lurus pada lengan Utara dan Selatan pada jam puncak 06.30 - 07.30 WIB. Hasil simulasi perubahan urutan fase dan mengoptimalisasikan waktu siklus simpang merupakan cara terbaik untuk menurunkan nilai tundaan menjadi 61,81 detik/kend dengan rasio belok kanan $10 \%$ dan lurus $90 \%$.
\end{abstract}

Kata-kata kunci: optimalisasi waktu siklus, PTV VISSIM, rasio belok, simpang bersinyal

\section{PENDAHULUAN}

Yogyakarta sebagai salah satu daerah kunjungan wisata yang sangat potensial dan perannya sebagai kota pendidikan yang terkemuka menjadi daya tarik bagi warga masyarakat di luar wilayah Daerah Istimewa Yogyakarta untuk datang dan bahkan menetap di wilayah Yogyakarta (Muchlisin, 2017). Hal tersebut membuat kota ini dikunjungi banyak orang dari berbagai daerah baik di dalam maupun luar negeri. Banyaknya kunjungan tersebut tentu dapat menaikan volume lalu lintas yang berada di jalanan khususnya ketika para pelajar berdatangan dengan membawa alat transportasi mereka dari daerah mereka masing-masing. Permasalahan akan muncul ketika volume lalu lintas mendekati/melebihi kapasitas suatu jalan dikarenakan ketidakseimbangan antara penyediaan jaringan jalan (supply) dengan volume lalu lintas (demand) (Mahmudah dkk., 2016). Masalah lalu lintas perkotaan merupakan faktor penting yang mempengaruhi pembangunan dan membatasi pembangunan ekonomi kota-kota, (Bambode \& Gajghate, 2014). Meningkatnya volume lalu lintas sering terjadi di simpang bersinyal maupun tak bersinyal. Sinyal lalu lintas dapat dilihat sebagai tulang punggung dalam pengendalian arus lalu lintas di daerah perkotaan (Köhler \& Strehler, 2012). Hal tersebut dapat mengakibatkan terjadi kemacetan dan penurunan pelayanan jalan. Salah satu simpang di Yogyakarta yang mengalami kemacetan dan penurunan pelayanan jalan yaitu simpang bersinyal yang berada di daerah Wirobrajan. Melihat situasi yang ada, diperlukan upaya meningkatkan kinerja pada simpang. Penggunaan Manual Kapasitas Jalan Indonesia (MKJI) untuk analisis jalan di Indonesia saat ini dinilai tidak relevan terhadap kondisi lalulintas (Yulianto \& Munawar, 2017), sehingga dibutuhkan pembanding dengan menggunakan Software Verkehr In Stadten Simulation Modell (VISSIM). Program VISSIM terbukti menjadi program unggulan untuk simulasi lalu lintas mikroskopik sejak di perkenalkan pada tahun 1992 (Aryandi \& Munawar, 2014). VISSIM termasuk dalam perangkat lunak dengan kategori mikroskopik yang memiliki keunggulan yaitu dapat memodelkan berbagai jenis kendaraan termasuk sepeda motor dan kendaraan tidak bermotor (Lubis \& Subakti, 2016). Hasil yang didapatkan hampir sama sehingga dapat dikatakan valid 
(Lu dkk., 2016). VISSIM dapat digunakan untuk pemodelan simpang tak bersinyal menjadi simpang bersinyal (Saputro dkk., 2018). Selain itu program VISSIM juga dapat digunakan untuk mengevaluasi dan perencanaan berbagai macam alternatif rekayasa transportasi yang efektif pada simpang (Pamusti dkk., 2017). VISSIM bisa digunakan untuk membangun sebuah prototype pada simulasi jalan raya pada kondisi dan dengan karakteristik dari kendaraan yang berbeda (Hormansyah dkk., 2016), Park dan Schneeberger (2003) melakukan penelitian simulasi kalibrasi dan validasi menggunakan VISSIM dimana hasil dari penelitian tersebut dapat digunakan karena hasil simulasi mendekati data yang ada di lapangan. Pada penelitian ini, upaya yang dilakukan yaitu dengan melakukan analisis dan pemodelan ulang, melakukan perubahan fase, serta mengoptimalisasikan waktu siklus simpang bersinyal Wirobrajan menggunakan (VISSIM).

\section{METODE PENELITIAN}

Secara umum metode yang digunakan dalam penelitian ini yaitu menggunakan metode survei lalu lintas di lapangan dan pemodelan menggunakan program VISSIM. Penelitian ini dilakukan di simpang empat bersinyal Wirobrajan, Yogyakarta. Ilustrasi lokasi dapat dilihat pada Gambar 1. Kondisi geometrik jalan pada simpang tersebut diberikan sebagai berikut :
1. Lebar lengan utara $=14,9 \mathrm{~m}$
2. Lebar lengan timur $=13,8 \mathrm{~m}$
3. Lebar lengan selatan $=15,2 \mathrm{~m}$
4. Lebar lengan barat $=13,8 \mathrm{~m}$

Data yang diperoleh dari pengambilan data di lapangan, kemudian dimasukkan ke dalam VISSIM 10.0. Analisis yang dilakukan nanti akan menghasilkan animasi 2D dan 3D serta menghasilkan output-output yang nantinya akan digunakan dalam pembahasan penelitian ini. Hasil-hasil yang digunakan berupa kondisi eksisting dan beberapa skenario simpang yang memungkinkan untuk bisa digunakan dalam pembahasan penelitian ini. Dalam penelitian ini menggunakan program VISSIM 10.0. Langkah - langkah dalam proses pemodelan:

1. Memasukan peta lokasi simpang, kemudian membuat jaringan jalan berupa link dan connector sesuai data yang ada di lapangan.

2. Menentukan jenis kendaraan yang sudah dikelompokan, vehicle types, vehicle classes.

3. Menentukan rute kendaraan, kecepatan kendaraan sesuai data yang ada.

4. Input volume kendaraan dan mengatur waktu sinyal.

\section{HASIL DAN PEMBAHASAN}

Volume jam puncak yang didapatkan dari surrvei pada jam 06.00 - 08.00 WIB, $12.00-14.00$ WIB, dan 16.00 - 18.00 WIB yaitu seperti disajikan pada Gambar 2. Kecepatan kendaraan sebelum dan sesudah masuk simpang disajikan pada Tabel 1 dan dapat dijelaskan seperti pada Gambar 3. Berdasarkan percobaan yang dilakukan didapatkan skenario untuk mengetahui faktorfaktor urutan fase dan menentukan nilai rasio terbaik untuk perubahan urutan fase. Model perubahan fase bisa dilihat pada Gambar 4

1. Kondisi eksisting yaitu pemodelan pada kondisi eksisting menggunakan data -data yang sama pada lapangan.

2. Skenario 1 yaitu dengan merubah fase pada lengan utara dan lengan selatan menjadi fase yang berbeda. Kemudian merubah lajur lengan utara dan lengan selatan dari 2 lajur menjadi 3 lajur yang digunakan untuk lajur belok kiri, belok kanan, dan lurus (lihat Gambar 5).

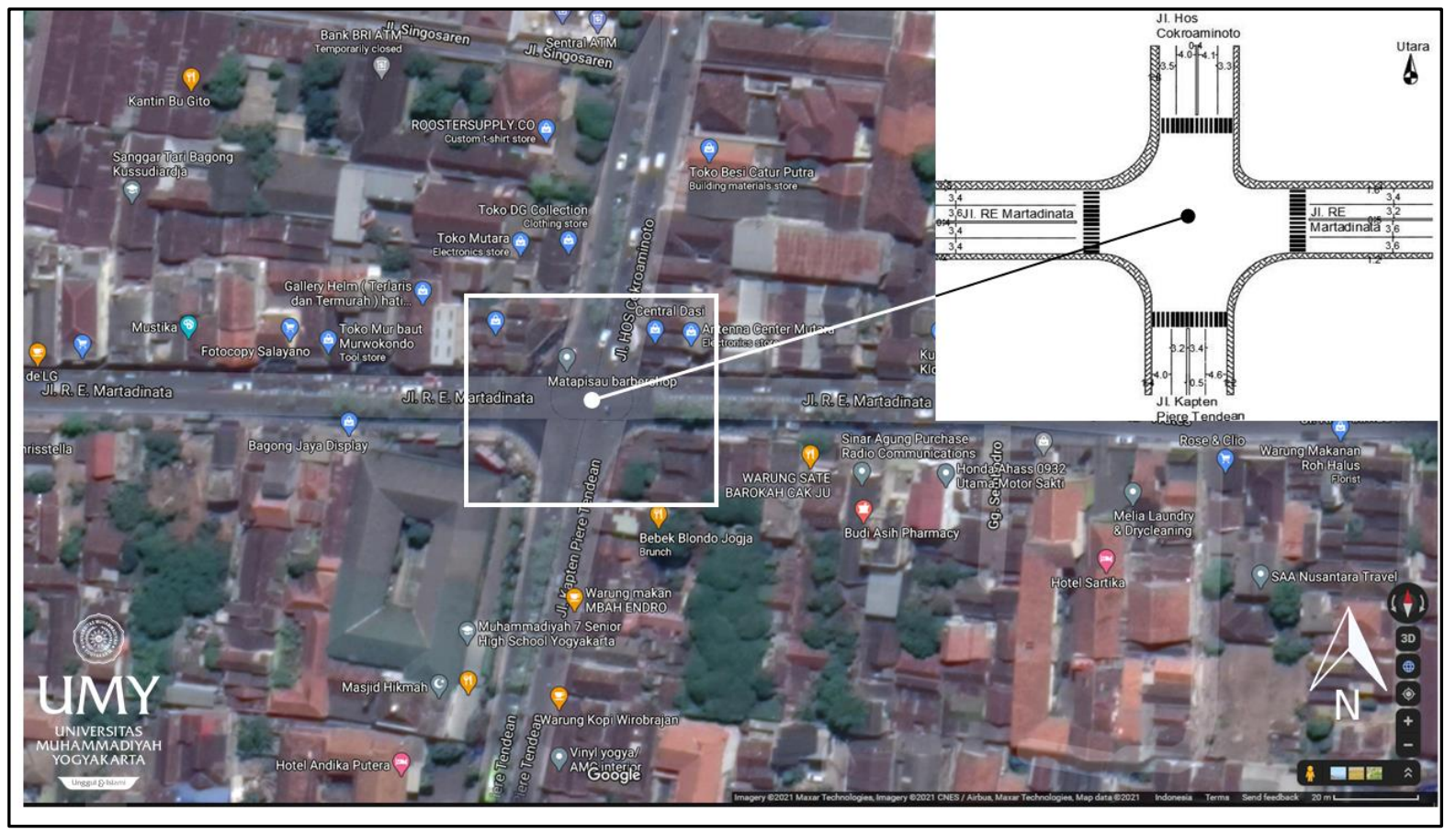

Gambar 1. Lokasi Penelitian dan. Kondisi Geometrik Jalan 


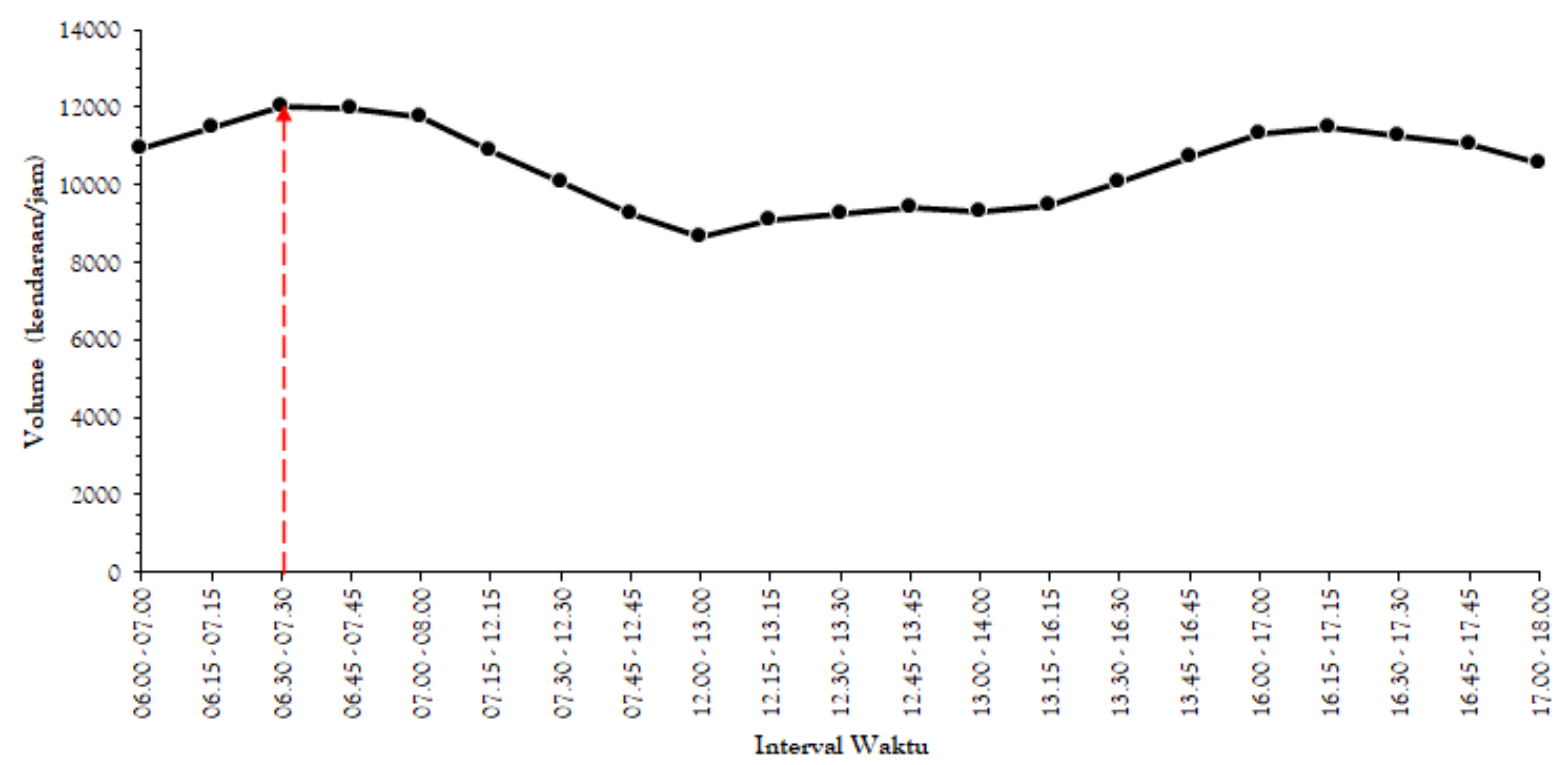

Gambar 2. Grafik Volume Jam Puncak

Tabel 1 Data kecepatan sebelumdan sesudah memasuki simpang (kendaraan/jam)

\begin{tabular}{|c|c|c|c|c|c|c|}
\hline \multirow{2}{*}{ Lengan } & \multicolumn{3}{|c|}{ Sebelum } & \multicolumn{3}{|c|}{ Sesudah } \\
\hline & $\mathrm{HV}$ & LV & $\mathrm{MC}$ & $\mathrm{HV}$ & LV & $\mathrm{MC}$ \\
\hline \multirow{5}{*}{ Utara } & 40 & 20 & 23 & 21 & 26 & 38 \\
\hline & 31 & 23 & 28 & 23 & 26 & 25 \\
\hline & 19 & 40 & 30 & 19 & 27 & 28 \\
\hline & 35 & 42 & 43 & 17 & 24 & 21 \\
\hline & 23 & 21 & 31 & 22 & 16 & 18 \\
\hline \multirow{5}{*}{ Selatan } & 20 & 33 & 30 & 18 & 27 & 20 \\
\hline & 27 & 32 & 38 & 18 & 26 & 23 \\
\hline & 38 & 38 & 28 & 20 & 20 & 21 \\
\hline & 37 & 34 & 31 & 22 & 25 & 36 \\
\hline & 27 & 37 & 38 & 17 & 31 & 25 \\
\hline \multirow{5}{*}{ Barat } & 23 & 33 & 39 & 17 & 21 & 24 \\
\hline & 26 & 31 & 41 & 19 & 18 & 22 \\
\hline & 25 & 36 & 38 & 31 & 20 & 25 \\
\hline & 17 & 34 & 37 & 20 & 22 & 20 \\
\hline & 32 & 32 & 37 & 18 & 19 & 24 \\
\hline \multirow{5}{*}{ Timur } & 23 & 32 & 28 & 19 & 28 & 36 \\
\hline & 28 & 40 & 29 & 22 & 30 & 30 \\
\hline & 31 & 27 & 30 & 20 & 30 & 31 \\
\hline & 19 & 25 & 29 & 23 & 22 & 18 \\
\hline & 35 & 27 & 27 & 25 & 22 & 26 \\
\hline
\end{tabular}

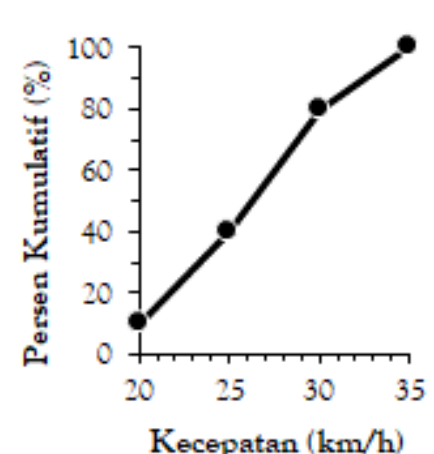

(a)

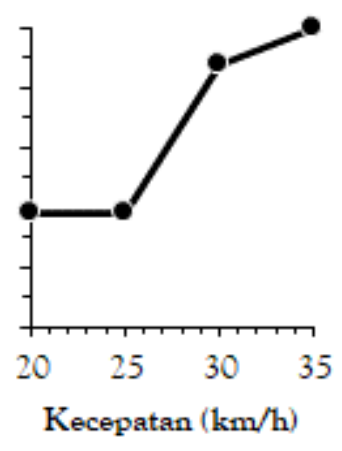

(b)



(c)



(d)

Gambar 3. Contoh grafik kumulatif LV di tiap lengan (a) selatan, (b) barat, (c) timur, (d) utara

3. Skenario 2 yaitu lanjutan dari skenario 1 , Skenario ini yaitu mengoptimalisasikan waktu siklus. Pengaturan penyesuaian waktu siklus menggunakan metode MKJI 1997 dilakukan berdasarkan fase dan volume arus lalu lintas pada jam puncak yang terjadi pada simpang tersebut seperti yang ditunjukkan pada Gambar6.

Hasil simulasi pada kondisi eksisting, skenario 1, skenario 2 dapat dilihat pada Tabel 2,3, dan 4 yang kemudian dipadukan pada Tabel 5 dan Gambar 7 . 


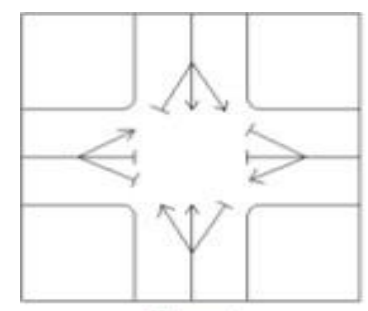

Fase 1

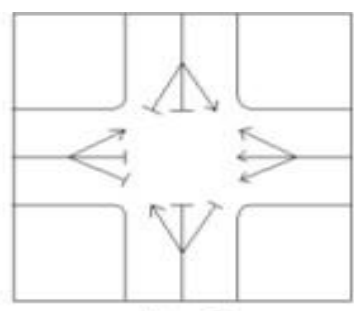

Fase 2

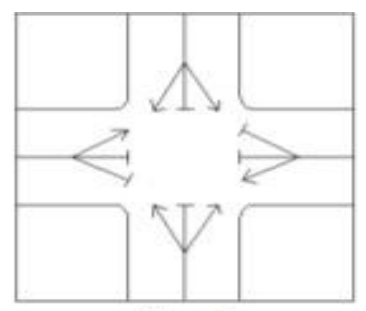

Fase 3

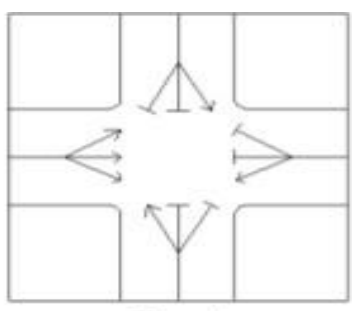

Fase 4

Gambar 4 Perubahan urutan fase

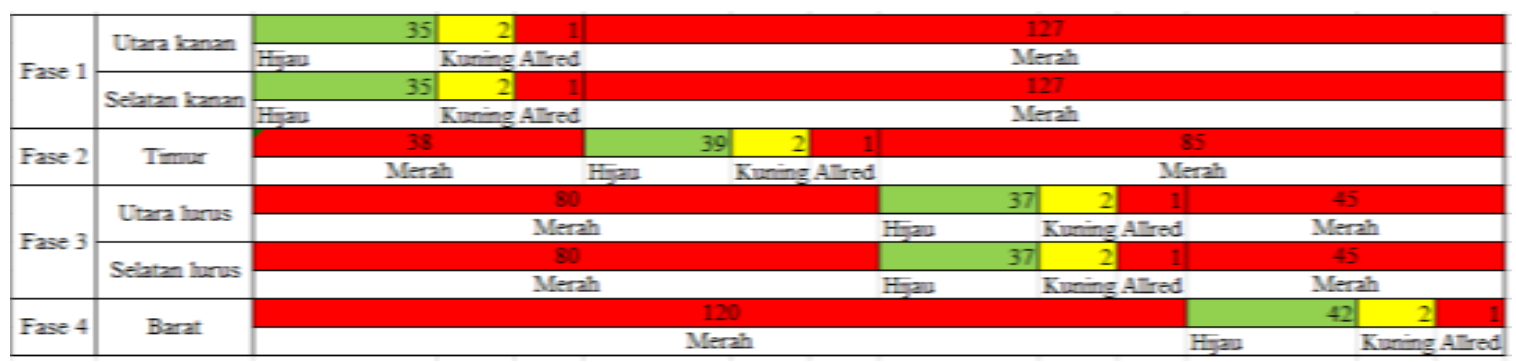

Gambar 5 Waktu siklus Skenario 1

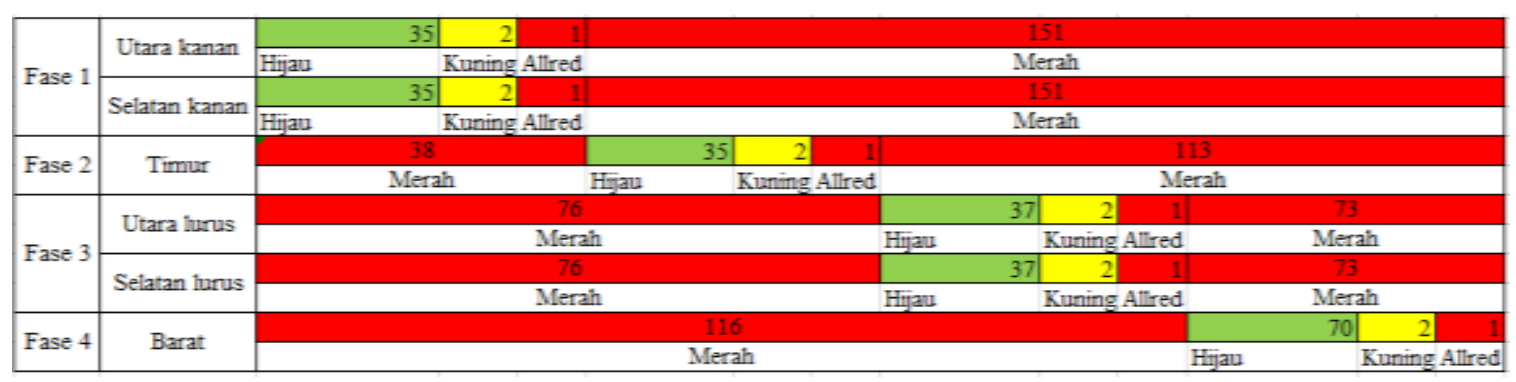

Gambar 6 Waktu siklus Skenario 2

Perubahan urutan fase dipengaruhi oleh presentase rasio belok dan volume pada lengan utara dan selatan, berdasarkan percobaan yang dilakukan secara trial and error (perbandingan rasio belok kanan dan lurus dari $90 \%$ dan 10\%, dst) seperti tabel di atas. Berdasarkan Tabel 5 dan Gambar 7, perubahan persentase rasio belok dan pengaturan ulang waktu siklus didapatkan hasil terbaik pada skenario 2. Pada lengan utara dengan rasio lurus 90\% dengan volume 1410,3 kendaraan/jam, rasio belok kanan 10\% dengan volume 156,7 kendaraan/jam. Pada lengan selatan dengan rasio lurus $90 \%$ dengan volume 1721,7 kendaraan /jam, rasio belok kanan 10\% dengan volume 191,3 kendaraan/jam. Serta nilai tundaan ratarata sebesar 61,81 detik/kendaraan dan tingkat pelayanan E.

Berdasarkan Tabel 5 dan Gambar 7, perubahan persentase rasio belok dan pengaturan ulang waktu siklus didapatkan hasil terbaik pada skenario 2. Pada lengan utara dengan rasio lurus $90 \%$ dengan volume kendaraan 1410,3 kendaraan /jam, rasio belok kanan 10\% dengan volume 156,7 kendaraan/jam. Pada lengan selatan dengan rasio lurus 90\% dengan volume 1721,7 kendaraam/jam, rasio belok kanan 10\% dengan volume 191,3 kendaraan/jam. Serta nilai tundaan rata-rata sebesar 61,81 detik/ kendaraan dan tingkat pelayanan E.

\section{KESIMPULAN}

Berdasarkan hasil penelitian yang dilakukan dengan menggunakan software VISSIM, diperoleh kesimpulan hasil sebagai berikut:

1. Hasil pemodelan menggunakan software didapatkan kinerja simpang pada kondisi eksisting dengan nilai tundaan sebesar 77,09 detik/kend dengan tingkat pelayanan "E".

2. Urutan pada fase dipengaruhi oleh perubahan rasio belok dan volume, nilai tundaan dan nilai LOS berdasarkan rasio belok dan volume sebagai berikut:

a. Kondisi eksisting didapatkan nilai tundaan terkecil yaitu 74,74 detik/kend dengan rasio belok kanan 60\% dan lurus $40 \%$ dengan tingkat pelayanan E.

b. Skenario 1 didapatkan nilai tundaan terkecil yaitu 68,33 detik/kend dengan rasio belok kanan $20 \%$ dan rasio lurus $80 \%$ dengan tingkat pelayan E. Nilai tersebut mengalami penurunan dibandingkan dengan rasio yang diperoleh di lapangan.

c. Skenario 2 didapatkan nilai tundaan terkecil yaitu 61,81 detik/kend dengan rasio lurus 90\% dan belok kanan 10\% dengan tingkat pelayan E. 
Wulandari \& Muchlisin / Buletin Teknik Sipil 1:1 (2021) 13-18

3. Nilai tundaan dan tingkat pelayanan yang diperoleh dari ke tiga percobaan diatas, dapat diperoleh hasil bahwa urutan fase yang efektif akan dapat berjalan baik bila waktu siklus ditetapkan sesuai dengan percobaan yang telah dilakukan pada skenario 2 yaitu saat rasio belok kanan 10\% dan lurus 90\%.

Tabel 2. Perbandingan Rasio Belok Kondisi Eksisting

\begin{tabular}{|c|c|c|c|c|c|c|c|c|}
\hline \multirow[b]{2}{*}{ No } & \multirow[b]{2}{*}{$\begin{array}{l}\text { Tahapan } \\
\text { Analsis }\end{array}$} & \multirow[b]{2}{*}{ Arah } & \multicolumn{2}{|c|}{ Lengan Utara } & \multicolumn{2}{|c|}{ Lengan Selatan } & \multirow[b]{2}{*}{$\begin{array}{l}\text { Tundaan } \\
\text { (detik/kend) }\end{array}$} & \multirow[b]{2}{*}{ LOS } \\
\hline & & & Rasio (\%) & $\begin{array}{l}\text { Volume } \\
\text { (kend/jam) }\end{array}$ & Rasio (\%) & $\begin{array}{l}\text { Volume } \\
\text { (kend/jam) }\end{array}$ & & \\
\hline \multirow{2}{*}{1} & Kondisi & Lurus & 67 & 1333 & 75 & 1290 & \multirow{2}{*}{77,09} & \multirow[b]{2}{*}{$\mathrm{E}$} \\
\hline & Eksisting & Kanan & 33 & 438 & 25 & 623 & & \\
\hline \multirow{2}{*}{2} & & Lurus & 90 & 1410,3 & 90 & 1721,7 & \multirow{2}{*}{75,53} & \multirow[b]{2}{*}{$\mathrm{E}$} \\
\hline & Irial 1 & Kanan & 10 & 156,7 & 10 & 191,3 & & \\
\hline \multirow{2}{*}{3} & \multirow{2}{*}{ Trial 2} & Lurus & 80 & 1253,6 & 80 & 1530,4 & \multirow{2}{*}{76,28} & \multirow{2}{*}{$\mathrm{E}$} \\
\hline & & Kanan & 20 & 313,4 & 20 & 382,6 & & \\
\hline \multirow{2}{*}{4} & \multirow{2}{*}{ Trial 3} & Lurus & 70 & 1096,9 & 70 & 1339,1 & \multirow{2}{*}{75,28} & \multirow[b]{2}{*}{$\mathrm{E}$} \\
\hline & & Kanan & 30 & 470,1 & 30 & 573,9 & & \\
\hline \multirow{2}{*}{5} & \multirow{2}{*}{ Trial 4} & Lurus & 60 & 940,2 & 60 & 1147,8 & \multirow{2}{*}{75,67} & \multirow{2}{*}{$\mathrm{E}$} \\
\hline & & Kanan & 40 & 626,8 & 40 & 765,2 & & \\
\hline \multirow{2}{*}{6} & \multirow{2}{*}{ Trial 5} & Lurus & 50 & 783,5 & 50 & 956,5 & \multirow{2}{*}{75,48} & \multirow{2}{*}{$\mathrm{E}$} \\
\hline & & Kanan & 50 & 783,5 & 50 & 956,5 & & \\
\hline \multirow{2}{*}{7} & \multirow{2}{*}{ Trial 6} & Lurus & 40 & 626,8 & 40 & 765,2 & \multirow{2}{*}{74,74} & \multirow{2}{*}{ E } \\
\hline & & Kanan & 60 & 940,2 & 60 & 1147,8 & & \\
\hline \multirow{2}{*}{8} & & Lurus & 30 & 470,1 & 30 & 573,9 & & $\mathrm{~F}$ \\
\hline & I rial 7 & Kanan & 70 & 1096,9 & 70 & 1339,1 & 75,34 & E \\
\hline 9 & Trial 8 & Lurus & 20 & 313,4 & 20 & 382,6 & 76.54 & $E$ \\
\hline 9 & I rial 8 & Kanan & 80 & 1253,6 & 80 & 1530,4 & 10,54 & $\mathrm{E}$ \\
\hline 10 & Trial 0 & Lurus & 10 & 156,7 & 10 & 191,3 & 7650 & $\mathrm{~F}$ \\
\hline 10 & I rial 9 & Kanan & 90 & 1410,3 & 90 & 1721,7 & 10,59 & $\mathrm{E}$ \\
\hline
\end{tabular}

Tabel 3. Perbandingan Rasio Belok Kondisi Skenario 1

\begin{tabular}{|c|c|c|c|c|c|c|c|c|}
\hline \multirow[b]{2}{*}{ No } & \multirow[b]{2}{*}{$\begin{array}{l}\text { Tahapan } \\
\text { Analsis }\end{array}$} & \multirow[b]{2}{*}{ Arah } & \multicolumn{2}{|c|}{ Lengan Utara } & \multicolumn{2}{|c|}{ Lengan Selatan } & \multirow[b]{2}{*}{$\begin{array}{l}\text { Tundaan } \\
\text { (detik/kend) }\end{array}$} & \multirow[b]{2}{*}{ LOS } \\
\hline & & & Rasio (\%) & $\begin{array}{l}\text { Volume } \\
\text { (kend/jam) }\end{array}$ & Rasio (\%) & $\begin{array}{l}\text { Volume } \\
\text { (kend/jam) }\end{array}$ & & \\
\hline \multirow{2}{*}{1} & Kondisi & Lurus & 67,4334 & 1333 & 75,2682 & 1290 & \multirow{2}{*}{70,88} & \multirow{2}{*}{ E } \\
\hline & Eksisting & Kanan & 32,5667 & 438 & 24,7318 & 623 & & \\
\hline 2 & Trial 1 & Lurus & 90 & 1410,3 & 90 & 1721,7 & 70,4 & E \\
\hline \multirow{2}{*}{3} & Trial? & Lurus & 80 & 1253,6 & 80 & 1530,4 & \multirow{2}{*}{68,33} & \multirow{2}{*}{ E } \\
\hline & 1 rial 2 & Kanan & 20 & 313,4 & 20 & 382,6 & & \\
\hline \multirow[t]{2}{*}{4} & Trial 3 & Lurus & 70 & 1096,9 & 70 & 1339,1 & \multirow{2}{*}{70,17} & \multirow{2}{*}{ E } \\
\hline & К⿴囗十 & $\begin{array}{l}\text { Kanan } \\
\text { Lurus }\end{array}$ & $\begin{array}{l}30 \\
60\end{array}$ & $\begin{array}{l}470,1 \\
940,2\end{array}$ & $\begin{array}{l}30 \\
60\end{array}$ & $\begin{array}{l}573,9 \\
1147,8\end{array}$ & & \\
\hline 5 & Trial 4 & Kanan & 40 & 626,8 & 40 & $765,2^{1}$ & 71,73 & $\mathrm{E}$ \\
\hline \multirow[t]{2}{*}{6} & Trial 5 & Lurus & 50 & $\begin{array}{r}783,5 \\
783,5\end{array}$ & 50 & 956,5 & \multirow{2}{*}{73,17} & \multirow[t]{2}{*}{ E } \\
\hline & & $\begin{array}{l}\text { Kanan } \\
\text { Lurus }\end{array}$ & $\begin{array}{l}50 \\
40\end{array}$ & $\begin{array}{l}783,5 \\
626,8\end{array}$ & $\begin{array}{l}50 \\
40\end{array}$ & $\begin{array}{l}956,5 \\
765,2\end{array}$ & & \\
\hline 7 & Trial 6 & Kanan & 60 & 940,2 & 60 & 1147,8 & 70,44 & E \\
\hline 8 & Trial 7 & $\begin{array}{l}\text { Lurus } \\
\text { Kanan }\end{array}$ & $\begin{array}{l}30 \\
70\end{array}$ & $\begin{array}{l}470,1 \\
1096,9\end{array}$ & $\begin{array}{l}30 \\
70\end{array}$ & $\begin{array}{l}573,9 \\
1339,1\end{array}$ & 71,37 & $\mathrm{E}$ \\
\hline \multirow{2}{*}{9} & Trial 8 & Lurus & 20 & 313,4 & 20 & 382,6 & \multirow{2}{*}{70,02} & \multirow{2}{*}{ E } \\
\hline & Irial 8 & Kanan & 80 & 1253,6 & 80 & 1530,4 & & \\
\hline \multirow{2}{*}{10} & Trial 9 & Lurus & 10 & 156,7 & 10 & 191,3 & \multirow{2}{*}{73,32} & $F_{1}$ \\
\hline & Irialy & Kanan & 90 & 1410,3 & 90 & 1721,7 & & $\mathrm{E}$ \\
\hline
\end{tabular}

Tabel 4. Perbandingan Rasio Belok Kondisi Skenario 2

\begin{tabular}{|c|c|c|c|c|c|c|c|c|}
\hline \multirow[b]{2}{*}{ No } & \multirow[b]{2}{*}{$\begin{array}{l}\text { Tahapan } \\
\text { Analsis }\end{array}$} & \multirow[b]{2}{*}{ Arah } & \multicolumn{2}{|c|}{ Lengan Utara } & \multicolumn{2}{|c|}{ Lengan Selatan } & \multirow[b]{2}{*}{$\begin{array}{l}\text { Tundaan } \\
\text { (detik/kend) }\end{array}$} & \multirow[b]{2}{*}{ LOS } \\
\hline & & & Rasio (\%) & $\begin{array}{l}\text { Volume } \\
\text { (kend/jam) }\end{array}$ & Rasio (\%) & $\begin{array}{l}\text { Volume } \\
\text { (kend/jam) }\end{array}$ & & \\
\hline \multirow{2}{*}{1} & Kondisi & Lurus & 67 & 1333 & 75 & 1290 & \multirow{2}{*}{65,06} & \multirow{2}{*}{$\mathrm{E}$} \\
\hline & Eksisting & Kanan & 32 & 438 & 25 & 623 & & \\
\hline \multirow{2}{*}{2} & \multirow{2}{*}{ Trial 1} & Lurus & 90 & 1410,3 & 90 & 1721,7 & \multirow{2}{*}{61,81} & \multirow{2}{*}{$\mathrm{E}$} \\
\hline & & Kanan & 10 & 156,7 & 10 & 191,3 & & \\
\hline \multirow{2}{*}{3} & \multirow{2}{*}{ Trial 2} & Lurus & 80 & 1253,6 & 80 & 1530,4 & \multirow{2}{*}{62,65} & \multirow{2}{*}{ E } \\
\hline & & Kanan & 20 & 313,4 & 20 & 382,6 & & \\
\hline \multirow{2}{*}{4} & \multirow{2}{*}{ Trial 3} & Lurus & 70 & 1096,9 & 70 & 1339,1 & \multirow{2}{*}{61,92} & \multirow{2}{*}{$\mathrm{E}$} \\
\hline & & Kanan & 30 & 470,1 & 30 & 573,9 & & \\
\hline \multirow{2}{*}{5} & \multirow{2}{*}{ Trial 4} & Lurus & 60 & 940,2 & 60 & 1147,8 & \multirow{2}{*}{66,12} & \multirow{2}{*}{ E } \\
\hline & & Kanan & 40 & 626,8 & 40 & 765,2 & & \\
\hline \multirow{2}{*}{6} & \multirow{2}{*}{ Trial 5} & Lurus & 50 & 783,5 & 50 & 956,5 & \multirow{2}{*}{65,15} & \multirow{2}{*}{$\mathrm{E}$} \\
\hline & & Kanan & 50 & 783,5 & 50 & 956,5 & & \\
\hline \multirow{2}{*}{7} & \multirow{2}{*}{ Trial 6} & Lurus & 40 & 626,8 & 40 & 765,2 & \multirow{2}{*}{66,07} & \multirow{2}{*}{$\mathrm{E}$} \\
\hline & & Kanan & 60 & 940,2 & 60 & 1147,8 & & \\
\hline 8 & & Lurus & 30 & 470,1 & 30 & 573,9 & & $\mathrm{~F}$ \\
\hline 8 & I rial 7 & Kanan & 70 & 1096,9 & 70 & 1339,1 & 05,04 & $\mathrm{E}$ \\
\hline & Trial 8 & Lurus & 20 & 313,4 & 20 & 382,6 & 6383 & $\mathrm{~F}$ \\
\hline 9 & & Kanan & 80 & 1253,6 & 80 & 1530,4 & & $\mathrm{E}$ \\
\hline 10 & Trial 9 & Lurus & 10 & 156,7 & 10 & 191,3 & 6567 & $\mathrm{~F}$ \\
\hline 10 & I rial y & Kanan & 90 & 1410,3 & 90 & 1721,7 & 05,01 & E \\
\hline
\end{tabular}


Tabel 5. Perbandingan Kerja Simpang

\begin{tabular}{|c|c|c|c|c|c|c|c|c|}
\hline \multirow[b]{2}{*}{ No } & \multirow[b]{2}{*}{$\begin{array}{l}\text { Tahapan } \\
\text { Analsis }\end{array}$} & \multirow[b]{2}{*}{ Arah } & \multicolumn{2}{|c|}{ Lengan Utara } & \multicolumn{2}{|c|}{ Lengan Selatan } & \multirow[b]{2}{*}{$\begin{array}{l}\text { Tundaan } \\
\text { (detik/kend) }\end{array}$} & \multirow[b]{2}{*}{ LOS } \\
\hline & & & $\begin{array}{l}\text { Rasio } \\
\text { Belok } \\
(\%)\end{array}$ & $\begin{array}{l}\text { Volume } \\
\text { (kend/jam) }\end{array}$ & $\begin{array}{l}\text { Rasio } \\
\text { Belok } \\
(\%)\end{array}$ & $\begin{array}{l}\text { Volume } \\
\text { (kend/jam) }\end{array}$ & & \\
\hline 1 & $\begin{array}{l}\text { Kondisi } \\
\text { Eksisting }\end{array}$ & $\begin{array}{l}\text { Lurus } \\
\text { Kanan }\end{array}$ & $\begin{array}{l}40 \\
60 \\
\end{array}$ & $\begin{array}{l}626,8 \\
940,2 \\
\end{array}$ & $\begin{array}{l}40 \\
60 \\
\end{array}$ & $\begin{array}{l}765,2 \\
1147,8 \\
\end{array}$ & 74,74 & $\mathrm{E}$ \\
\hline 2 & $\begin{array}{l}\text { Skenario } \\
1\end{array}$ & $\begin{array}{l}\text { Lurus } \\
\text { Kanan }\end{array}$ & $\begin{array}{l}80 \\
20\end{array}$ & $\begin{array}{l}1253,6 \\
313,4\end{array}$ & $\begin{array}{l}80 \\
20\end{array}$ & $\begin{array}{l}1530,4 \\
382,6\end{array}$ & 68,33 & $\mathrm{E}$ \\
\hline 3 & $\begin{array}{l}\text { Skenario } \\
2\end{array}$ & $\begin{array}{l}\text { Lurus } \\
\text { Kanan }\end{array}$ & $\begin{array}{l}90 \\
10\end{array}$ & $\begin{array}{l}1410,3 \\
156,7\end{array}$ & $\begin{array}{l}90 \\
10\end{array}$ & $\begin{array}{l}1721,7 \\
191,3\end{array}$ & 61,81 & E \\
\hline
\end{tabular}

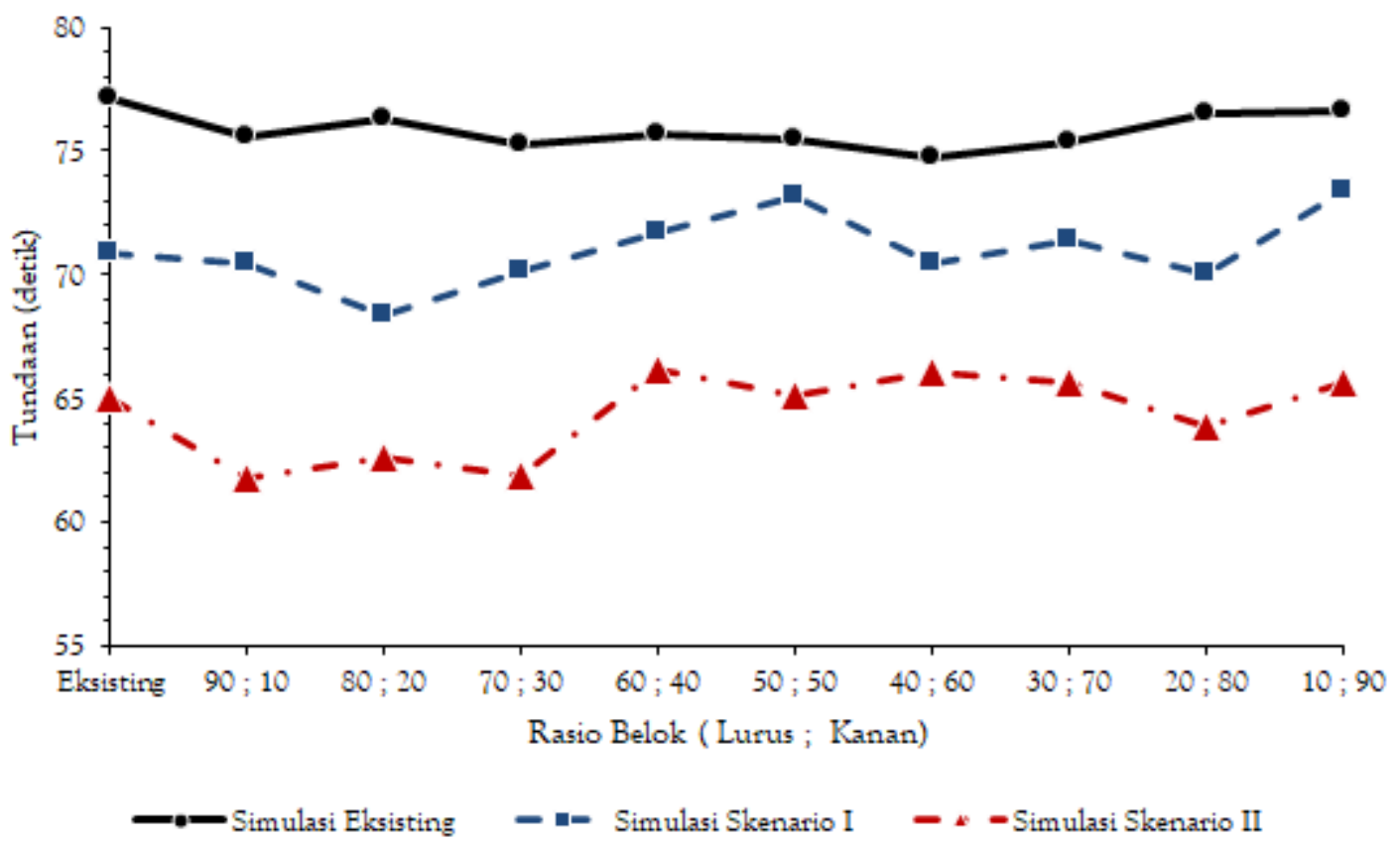

Gambar 7. Grafik perbandingan tundaan dan perubahan rasio belok

\section{Daftar Pustaka}

Aryandi, R. D. Munawar, A. 2014. Penggunaan Software VISSIM untuk Analisis Simpang Bersinyal (Studi Kasus Simpang Mirota Kampus Terban Yogyakarta) Proceeding The 17th FSTPT International Symposium, Jember, 22-24 Agustus 2014, 338-347.

Bambode, K., Gajghate, V. 2014. Traffic Signal Optimization for Important Routes In Nagpur City: A Review. International Journal of Emerging Technology and Advanced Engineering 2(4), 511-514.

Hormansyah, D. S., Sugiarto, V., Amalia,E. L. 2016. Penggunaan VISSIM Model Pada Jalur Lalu Lintas Empat Ruas. Jurnal Teknologi Informasi 7(1). 57-67.

Köhler, E., Strehler, M. 2012. Combining static and dynamic models for traffic signal optimization inherent loaddependent travel times in a cyclically time-expanded network model. Procedia-Social and Behavioral Sciences 54, 1125-1134.

Lubis, R. I. Surbakti, M.S. 2016. Analisa Arus Jenuh dan Panjang Antrian pada Simpang Bersinyal dan Mikro Simulasi Menggunakan Software VISSIM (Studi Kasus: Simpang Hotal Danau Toba Internasional dan Simpang Karya Wisata di Kota Medan). Jurnal Teknik Sipil 6(1), 1-10.

Lu, Z., Fu, T., Fu, L., Shiravi, S., Jiang, C.2016. A video-based approach to calibrating car-following parameters in
VISSIM for urban traffic. International Journal of Transportation Science and Technology 5(1), 1-9.

Mahmudah, N., Banyunagoro, D. K. Muchlisin, 2016, Pemodelan Lalu Lintas Pada Simpang Bersinyal Di Kota Yogyakarta (Studi Kasus Simpang Pingit), Proceeding Simposium Nasional Teknologi Terapan (SNTT) IV, Universitas Muhammadiyah Purwokerto, 26 November 2016, 596-603.

Muchlisin, M. 2017. Analisis Tarikan dan Bangkitan Perjalanan Akibat Pembangunan Mix-Used Plan (Mix- used JogjaOne Park) dengan Metode Pembanding. Semesta Teknika 19(2), 98-105.

Pamusti, G., Herman, H., Maulana, A. 2017. Kinerja Simpang Jalan Jakarta- Jalan Supratman Kota Bandung dengan Metode MKJI 1997 dan Software PTV VISSIM 9. Reka Racana 3(3), 1-11.

Park, B., Schneeberger, J. 2003. Microscopic simulation model calibration and validation: case study of VISSIM simulation model for a coordinated actuated signal system. Transportation Research Record 1856), 185-192.

Saputro, T. L., Putri, A. P., Suryaningsih, A., Putri, Z. S., Salahuddin, M. 2018. Kajian Simpang Tiga Tak Bersinyal Kariangau Km. 5, 5 Kelurahan Karang Joang Balikpapan Utara Menggunakan Permodelan VISSIM Menjadi Simpang Bersinyal. Jurnal Teknologi Terpadu 6(1), 36-43.

Yulianto, R. A., Munawar, A. 2017. Penentuan Kapasitas Jalan Bebas Hambatan Dengan Aplikasi Perangkat Lunak VISSIM. Jurnal Transportasi 17(2), 123-132 